\title{
А.Э.Хрулев, М.В.Кротов
}

\section{ВЛИЯНИЕ НЕИСПРАВНОСТЕЙ В СИСТЕМЕ СМАЗКИ НА ХАРАКТЕР ПОВРЕЖДЕНИЯ ПОДШИПНИКОВ ДВС}

\begin{abstract}
Выполнен анализ состояния подиипников ДВС при различных неисправностях в системе смазки, вызываюших уменьшение или даже полное прекращение подачи масла к подиипникам коленчатого вала. Установлено, что нарушение подачи масла приводит к двум главным видам повреждений подиипников - когда повреждены только коренные подшипники, речь может идти о полном или почти полном прекрашении подачи масла, в то время как повреждение только шатунных подшипников возникает при снижении подачи масла. Выявлено, что разница в характере повреждения коренных и шатунных подиипников связана не только с конструктивным различием организации подачи масла, но и с действием центробежных сил от вращения коленвала на столб масла в смазочном отверстии, подающем масло к иатуному подшипнику. Приведень и проанализированы основные признаки рассматриваемых видов повреждений, а путем разделения этих признаков на главные, подтверждающие и уточняющие, разработаны простые рекомендации по определению причин неисправности ДВС, связанных с повреждениями подиипников.
\end{abstract}

\section{Постановка задачи}

Многолетняя практика исследования неисправностей двигателей внутреннего сгорания показывает, что нарушение режима смазки в двигателе является одной из наиболее распространенных причин повреждений подшипников коленчатого вала в эксплуатации. Такое повреждение происходит в условиях граничного или сухого трения при недостаточной подаче масла, вследствие чего данный режим работы подшипников в двигателе получил название "масляное голодание".

За более чем 100 лет эксплуатации ДВС различных типов неисправности, повреждения и отказы узлов и деталей достаточно подробно изучены. Так, в известной технической литературе по неисправностям ДВС $[1,9,10]$ описаны многочисленные возможные причины повреждения подшипников, связанные с масляным голоданием. В некоторых источниках информации, включая технические каталоги повреждений деталей мировых производителей комплектующих - фирм Mahle, Kolbenschmidt, Clevite, King Bearings и др. [9-12], содержатся некоторые сведения, позволяющие даже как-то локализовать повреждение и уточнить его причину. При этом обычно указывается, что если повреждены все подшипники или их большинство, то речь идёт об общей недостаче масла, в том числе, могут иметь место самые разные причины, например:

- неисправный или негерметичный масляный насос, или же дефект редукционного клапана наcoca;

- утечки в масляной системе (чрезмерно большие зазоры, поломки заглушек, масляных форсунок и т.д.);

- засорение сетки маслоприемника;

- слишком низкий уровень масла;

- слишком большой наклон автомобиля.

Если же повреждён только один подшипник, то это считается локальной недостачей масла, для которой источники обычно дают следующие причины:

- установка вкладыша подшипника в неправильном положении - если одна половина подшипника имеет масляные каналы, а другая не имеет таковых, то в неправильном положении (наоборот) происходит перекрытие масляного канала в постели подшипника, и тогда масло не поступает в подшипник;

- засорение масляных каналов к поврежденному подшипнику посторонними предметами;

- полное отсутствие подачи масла к шейке (например, при поломке вала);

- прочие причины, в том числе, производственные, включая попадание под подшипник посторонних предметов, частиц, неправильная геометрия и др.

Очевидно, при анализе повреждения, ограниченного только одним подшипником, определение причины нарушения режима его смазки не вызывет больших трудностей, поскольку повреждение возможно только по весьма ограниченному числу причин, локализованных непосредственно у этого поврежденного подшипника [1, 2-5]. Однако при исследовании причины неисправности ДВС, в котором повреждены большинство или все подшипники коленвала, указанной информации, как правило, недостаточно. Кроме того, для многих практических случаев в литературе отсутствует подробное описание целого ряда наблюдаемых конкретных признаков повреждений, что нередко вызывает у специалистов большие сложности в определении действительных причин повреждения коренных и шатунных подшипников.

Цель данной работы - разработка рекомендаций для определения причин неисправностей подшипников ДВС в зависимости от характера их повреждений. 


\section{Особенности повреждения подшипников ДВС и их причины}

Как известно, коренные и шатунные подшипники в ДВС имеют различное конструктивное устройство подачи масла. Так, смазка коренных подшипников происходит моторным маслом, подаваемым к ним из поддона двигателя масляным насосом под давлением из главной масляной магистрали в блоке цилиндров. В то же время подача масла к шатунным подшипникам происходит от коренных подшипников по радиально-осевым масляным каналам, выполненным в коленчатом вале.
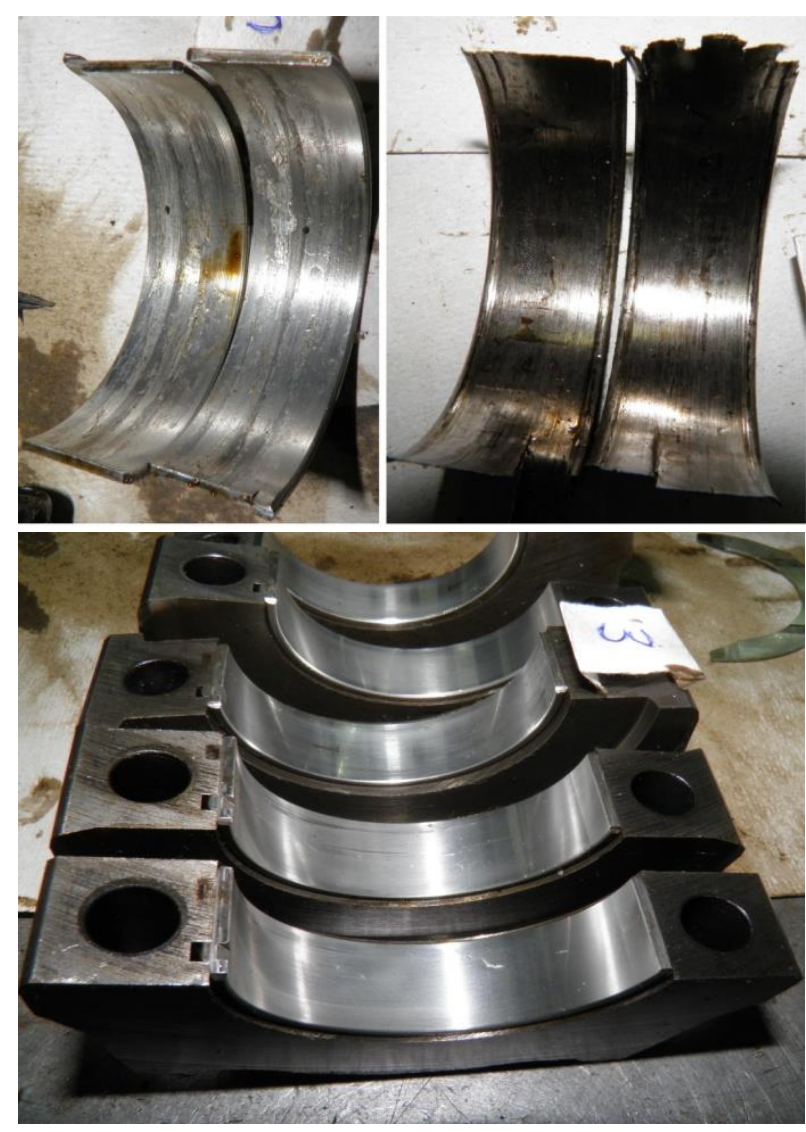

Pис.1. Типичный пример повреждения шатунных подшипников (вверху) при отсутствии заметных повреждений коренных подщипников (внизу) обычный результат эксплуатации двигателя с недостаточным уровнем масла

В процессе исследований причин неисправностей в системе смазки двигателей обычно выявляются следующие основные и наиболее часто встречающиеся виды повреждений подшипников коленвала [1, 2-5], которые можно разбить на 3 основных вида:

1) повреждены большинство или все шатунные подшипники (рис.1), с образованием следов масляного голодания на шатунных шейках коленвала, на рабочей поверхности подшипников в виде цветов побежалости металла, задиров, плавления и разрушения антифрикционного слоя подшипников, с повреждением кривошипных головок шатунов, при этом коренные подшипники следов повреждения не имеют или они незначительны,

2) повреждены большинство или все коренные подшипники (рис.2), с образованием следов масляного голодания на коренных шейках коленвала, на рабочей поверхности подшипников в виде цветов побежалости металла, задиров, плавления и разрушения антифрикционного слоя подшипников, с повреждениями на поверхности отверстий опор (постелей) коленвала в блоке цилиндров, при этом шатунные подшипники следов повреждения не имеют,

3) повреждены в той или иной степени и коренные, и шатунные подшипники, имеющие следы повреждения различной степени (рис.3).
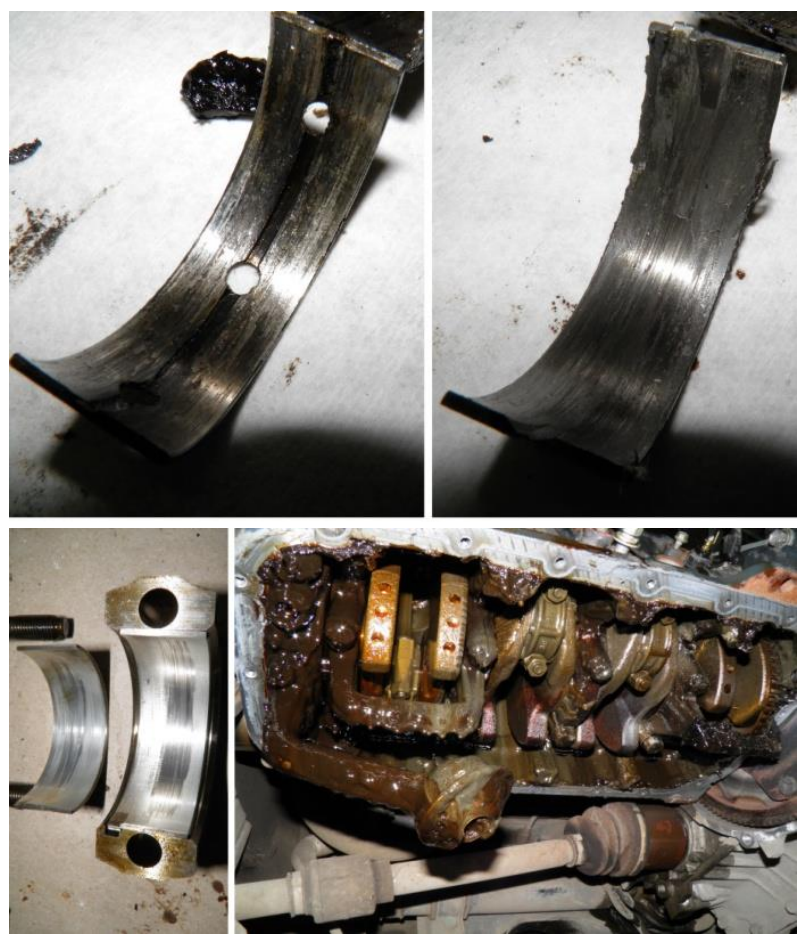

Рис.2. Противоположный случай - повреждения коренных подшипников с плавлением, заклиниванием вала и проворачиванием вкладышей в постелях (вверху), сопровождаемье сравнительно небольшими повреждениями шатунных подшипников (внизу), вызван чрезвычайно быстрой деградацией моторного масла с закупориванием сетки маслоприемника

Исходя из различий в условиях смазки шатунных и коренных подшипников, логично предположить, что в случае внезапного и полного прекращения подачи масла к коленчатому валу нарушение смазки возникнет в 1-ю очередь в тех подшипниках, 
куда смазка непосредственно подается под давлением. Тогда режим масляного голодания при быстром и полном прекращении подачи масла должен возникать, в 1-ю очередь, в коренных подшипниках коленвала.

Отсюда также следует, что наблюдаемое повреждение только шатунных подшипников (без повреждения коренных) возможно не только и не столько в случае полного отсутствия масла в смазочных отверстиях коленвала, сколько при снижении подачи масла, но не полного его прекращения (иначе повреждения получили бы и коренные подшипники).

Несмотря на эти очевидные особенности повреждения подшипников, практика показывает: некоторые специалисты при определении причины подобных неисправностей не принимают во внимание наблюдаемое различие в степени повреждения коренных и шатунных подшипников и указывают в результате на такие причины возникновения масляного голодания, которые прямо противоречат имеющимся признакам. В то же время наличие одновременного повреждения всех подшипников коленвала вызывает наибольшие трудности при определении достоверной причины повреждения, соответствующей реальной картине выхода двигателя из строя.
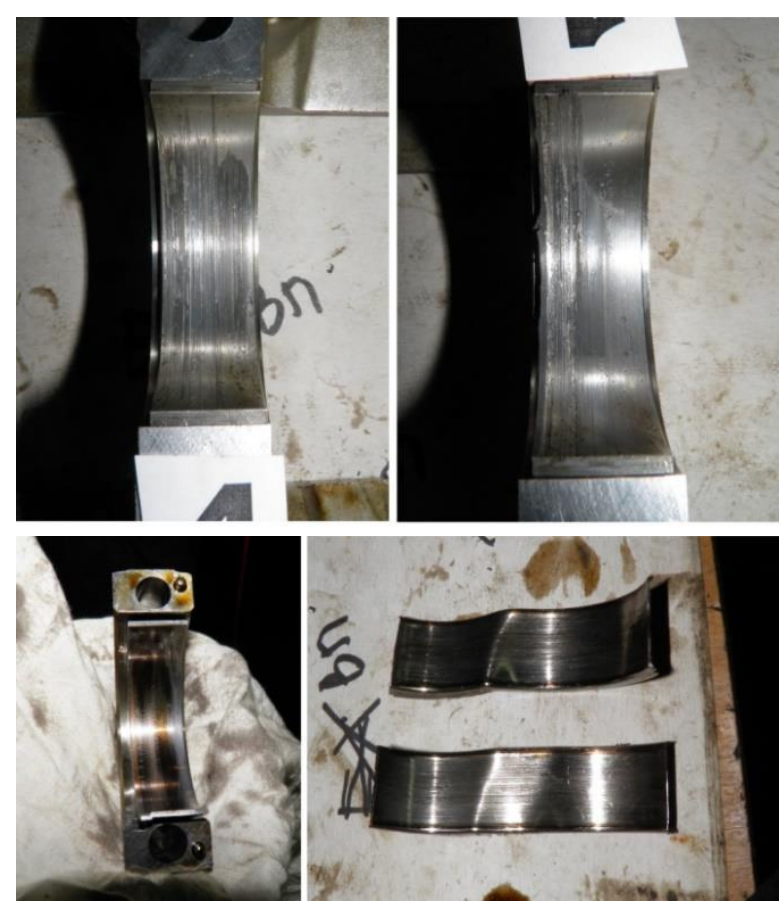

Рис.3. Пример повреждения всех подчипников - $и$ коренных (вверху), и шатунных (внизу), в результате длительной эксплуатации двигателя на мощцностных режимах при неисправном маслонасосе

Влияние конструкции коренных подшипников на смазку шатунных
Для того, чтобы выяснить причину, по которой в некоторых практических случаях повреждается только одна группа подшипников, необходимо еще раз рассмотреть хорошо известную всем конструктивную схему подшипников коленвала ДВС. Действительно, в подавляющем большинстве конструкций автомобильных ДВС коренные подшипники, помимо основной "подшипниковой" функции, выполняют и роль маслораспределителей для подачи масла к шатунным подшипникам. По мере роста удельных нагрузок, что связано с увеличением мощностных показателей, постепенно была выработана единая конструктивная схема коренных подшипников [6, 9-12], имеющая следущие отличительные особенности:

1) нижняя половина коренного вкладыша выполняется без маслосборной канавки, что необходимо из условия максимальной грузоподъемности и минимального эксплуатационного износа подшипника,

2) маслосборная канавка выполняется только на менее нагруженной верхней половине вкладыша,

3) на коленчатом валу выполняется одно или два отверстия для подачи масла из маслосборной канавки к шатунному подшипнику.

Анализ конструкций автомобильных ДВС, выпущенных в конце 20-го и начале 21-го веков показывает, что отверстия в коленчатом валу для подачи масла к шатунным подшипникам выполняются в 2-х вариантах (рис.4):
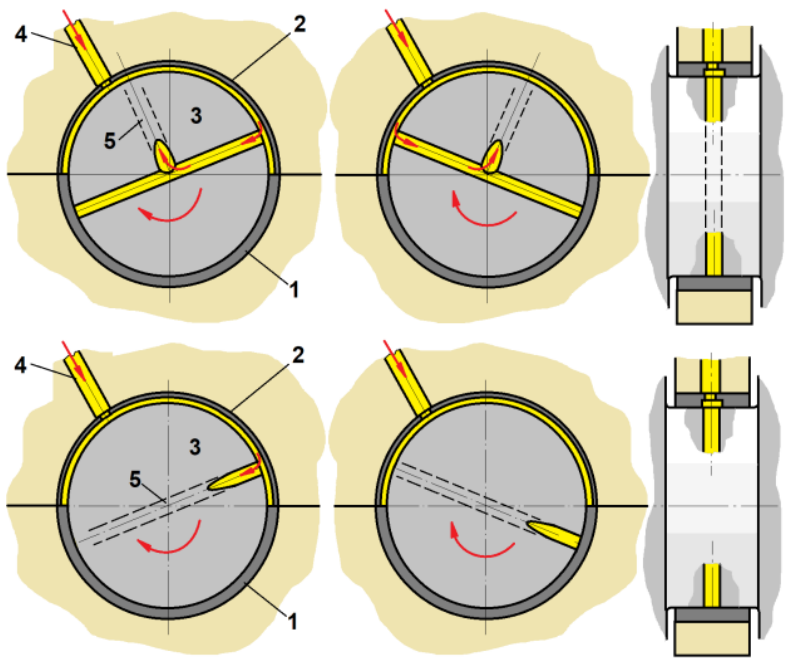

Рис.4. Конструктивные схемы коренного подшипника с непрерывной подачей масла через сквозное поперечное отверстие в коренной шейке (вверху) $u$ с прерывистой подачей масла через отверстие, соединяюшее коренную и шатунную шейки (внизу):

1- нижний вкладыи без канавки, 2- верхний вкладыш с канавкой, 3- коленвал, 4- канал подачи масла к коренной опоре, 5- канал подачи масла к шатунной шейке 
1) коренная шейка сверлится поперек по ее диаметру насквозь, затем выполняется отвертие в шатунной шейке до его соединения с отверстием в коренной,

2) сверлится только одно сквозное отверстие, соединяющее коренную и шатунную шейку.

Поскольку уменьшение себестоимости производства реализуется, в том числе, и путем сокращения числа производственных операций, наибольшее распространение постепенно получила схема с одним смазочным отверстием. Однако, как нетрудно заметить, установка коленчатого вала, имеющего только по одному отверстию в коренных шейках, в подшипники, у которых маслосборная канавка есть только на верхних половинах вкладышей, приводит к прерывистой подаче масла в смазочное отверстие коленвала, предназначенное для смазки шатунных подшипников.

Действительно, при вращении коленчатого вала отверстие подачи масла к шатунным подшипникам открыто только те полоборота, когда оно совпадает с маслосборной канавкой на верхнем вкладыше - остальные полоборота отверстие закрыто нижней половиной вкладыша, и никакой подачи масла в каналы смазки шатунных подшипников не происходит. Возникает вопрос: каким образом шатунный подшипник работает тогда без масла?

Ответ заключен в самом различии способов подачи масла к коренным и шатунным подшипникам к коренным масло поступает непрерывно и непосредственно из системы смазки от маслонасоса, а к шатунным оно идет от маслосборной канавки, причем расположение оси шатунной шейки со смещением на величину радиуса кривошипа (с эксцентриситетом) от оси коренных предполагает, что даже при полном перекрытии смазочного отверстия в коленвале подача масла к шатунным подшипникам неизбежно продолжится - за счет центробежных сил.

Поскольку различается не только способ подачи масла, но и, судя по имеющимся данным [1, 5], сам характер повреждения коренных и шатунных подшипников, вполне допустимо предположить, что эту разницу дает именно влияние центробежных сил. Поэтому рассмотрим более подробно, насколько такое влияние может быть существенным.

Оценка влияния центробежных сил на смазку шатунных подшипников

Рассмотрим упрощенную схему организации подачи масла от коренной шейки к шатунной (рис.5), приняв следующие допущения:

1) смазочное отверстие просверлено приблизительно по радиусу кривошипа,
2) течение масла в отверстии имеет свойство неразрывности,

3) подача масла от коренного подшипника перекрыта,

4) вращение вала идет с постоянной скоростью, равной 3000 мин $^{-1}$, что соответствует режиму средних оборотов.

Очевидно, давление масла Рмц в выходном сечении отверстия (на шатунной шейке) при таких условиях будет равно:

$$
P_{\text {мц }}=F_{ц} / f,
$$

где $F_{\text {ц }}=m v^{2} / R$ - центробежная сила, действующая на столб масла в отверстии, $\mathrm{H}, m=\rho f l$ масса столба масла, кг, $\rho$ - плотность масла (900 кг/ $\left.\mathrm{M}^{3}\right), \mathrm{f}$ - площадь проходного сечения отверстия, $\mathrm{M}^{2}, 1$ - длина столба масла, на который действуют неуравновешенная центробежная сила, м, $v=$ $\pi R n / 30$ - окружная скорость, м/с, на радиусе кривошипа $\mathrm{R}, \mathrm{n}$ - частота вращения, мин ${ }^{-1}$.

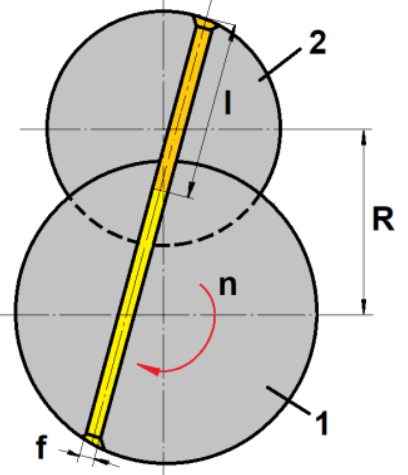

Pис.5. Схема подачи масла от коренной (1) к шатунной (2) шейке коленвала

Подставляя все выражения в формулу (1), получим давление масла от центробежных сил:

$$
P_{\text {мц }}=\rho l R n^{2}\left(\pi^{2} / 900\right) \text {. }
$$

Как это следует из схемы узла, радиус кривошипа и длина столба масла в отверстии - величины приблизительно равные, поэтому для простоты приравняем их друг другу - тогда формула для расчета давления масла в шатунных подшипниках от центробежных сил получит следующий простой окончательный вид:

$$
P_{\text {мц }}=\rho R^{2} n^{2}\left(\pi^{2} / 900\right) .
$$

Если принять среднюю величину радиуса кривошипа 0,05 м, то простейший расчет даст давление подачи масла Рмц = 2,2 бар. Отсюда прямо следуют, как минимум, три важных вывода:

1) прерывистой подачи масла к шатунным подшипникам нет даже в случае, если каждые полоборота коленвала смазочное отверстие на коренной шейке перекрывается нижним коренным вкладышем без канавки - подача масла обеспечивается непрерывно под действием центробежных сил 
на столб масла в смазочном отверстии,

2) возможность нормальной работы шатунных подшипников при отключении подачи масла в смазочное отверстие каждые полоборота коленвала прямо подтверждает тот факт, что даже при полном прекращении подачи масла в смазочное отверстие шатунный подшипник некоторое время будет продолжать нормальную работу,

3) при аварийном прекращении подачи масла к коренным подшипникам шатунные не остаются сразу без смазки, поскольку некоторое время давление масла в них обеспечивается действием центробежных сил, причем величина давления, создаваемого центробежными силами, действующими на столб масла в смазочном отверстии, вполне достаточна для нормальной работы подшипника (хотя и весьма ограниченное время - пока масло не будет полностью выдавлено из смазочного отверстия в шатунный подшипник).

Исходя из таких особенностей работы шатунных подшипников, есть все основания полагать, что именно наличием центробежных сил и объясняются отмечаемые в практике исследования причин неисправностей существенные различия в повреждениях коренных и шатунных подшипников. В частности, речь идет о тех случаях, когда заклинивание коленчатого вала в коренных подшипниках не сопровождается каким-либо повреждением шатунных. Тем не менее, объяснить некоторые неисправности данная теория может не всегда, поскольку не учитывает влияния режима работы двигателя на функционирование системы смазки.

Влияние режима работы двигателя на повреждения подшипников

Хорошо известно, что режим масляного голодания, который приводит к повреждению и последующему разрушению подшипника скольжения, первоначально возникает при недостаточной подаче масла к трущимся поверхностям подшипника, в результате чего при заданной нагрузке масляная пленка становится тоньше $[1,5,8]$. Уменьшение подачи масла в подшипник приводит к ухудшению отвода тепла и повышению температуры масла и самого подшипника, что снижает вязкость масла и еще больше уменьшает толщину его пленки. Это, в свою очередь, вызывает непосредственный контакт и разогрев подшипника от трения контактирующих деталей - вкладыша и шейки коленвала, в соответствии с режимом граничного трения, характеризующимся контактом по микронеровностям как начальной фазе повреждения.

Дальнейшее уменьшение подачи масла (и/или рост нагрузки на вал) приводит к расширению зон соприкосновения деталей и дальнейшему разогреву их поверхностей. В определенный момент масло полностью выдавливается из зазора, происходит переход в так называемый режим сухого трения, и начинается плавление рабочего слоя вкладыша. В условиях непосредственного контакта вала со вкладышем это ведет к переносу расплавленного рабочего слоя вкладыша на поверхность шейки вала (задирам), одновременно с этим расплавленный антифрикционный материал вкладыша выжимается под действием рабочей нагрузки к краям вкладыша.

При работе двигателя на низких оборотах и нагрузках на данной стадии расплавления подшипника и взаимного переноса материала может произойти заклинивание вала в подшипнике за счет приваривания деталей друг к другу. На высоких оборотах и у мощных двигателей такой эффект наблюдается реже, поскольку при большой развиваемой мощности двигатель преодолевает любую дополнительную силу сопротивления вращению коленчатого вала, сопутствующую разрушению вкладышей. В таких случаях, даже если вкладыши привариваются к валу, они проворачиваются в блоке цилиндров и/или кривошипной головке шатуна. Дальнейшая работа двигателя с данной неисправностью ведет к ее развитию и распространению повреждений на все большее число подшипников, в том числе, за счет вторичного их повреждения продуктами разрушения (рис.6), а также перекрытия каналов, в том числе, при проворачивании вкладышей в коренных постелях.

Указанная особенность развития начального повреждения на мощностных режимах, судя по имеющимся экспериментальным данным [1, 5], и является причиной того, что на практике наблюдаются не две характерных картины повреждений (повреждены или только коренные, или только шатунные подшипники), а три - к двум часто встречающимся вариантам добавляется третий, с повреждением и шатунных, и коренных подшипников.

Причем, чем больше нагрузка и обороты и длительнее работа двигателя после появления неисправности, тем, в целом, меньше различия в степени повреждения подшипников - вплоть до полного разрушения двигателя (рис.7).

Все указанные данные позволяют собрать вместе все возможные причины повреждения подшипников и характерные признаки нарушения режима смазки, чтобы путем сравнения с имеющимися признаками определить, по какой причине возникло повреждение подшипников коленвала. Для этого целесообразно воспользоваться принципами разделения признаков на главные, подтверждающие и уточняющие. 


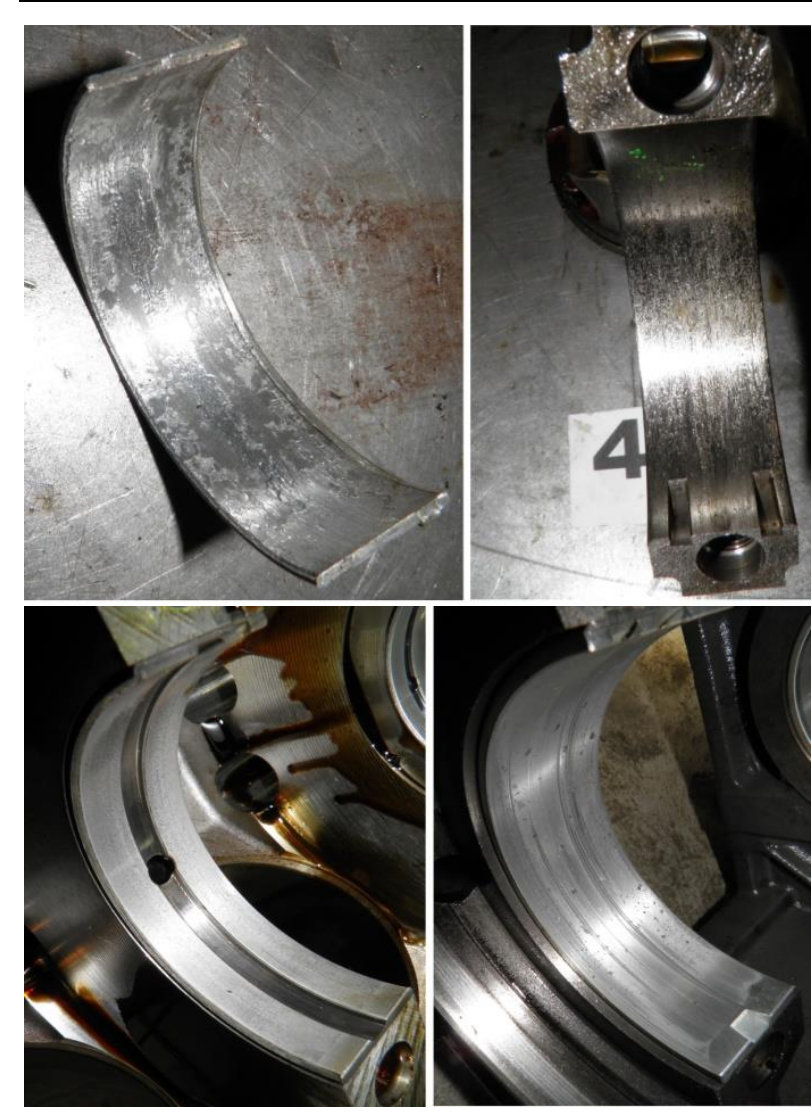

Рис.6. Пример значительного повреждения шатунных вкладышей с плавлением и разрушением рабочего слоя и проворачиванием в кривошипной головке шатуна (вверху) при незначительном повреждении коренных подшипников преимущественно частицами разрушения шатунных (внизу) - результат эксплуатаџии на масле с чрезмерно низкой вя-

зкостью, вызванной перегревом двигателя

Так, главным признаком неисправности является сам характер повреждения подшипников, а именно, какая группа подшипников повреждена шатунные, коренные или те и другие.

К подтверждающим признакам следует отнести такие особенности повреждения, как наличие или отсутствие заклинивания вала в подшипнике, проворачивания вкладыша в постели, перегрева и разрушения кривошипной головки шатуна. Это позволяет выявить причину неисправности по уточняющим признакам, в том числе, по состоянию маслонасоса, фильтра, сетки маслоприемника, целостности поддона картера, наличию течей и продуктов загрязнения масла, а также качества самого масла и других признаков, характеризующих состояние деталей.

Для наглядности все признаки, необходимые для определения состояния подшипников, сгруппированы и сведены в табл.1.

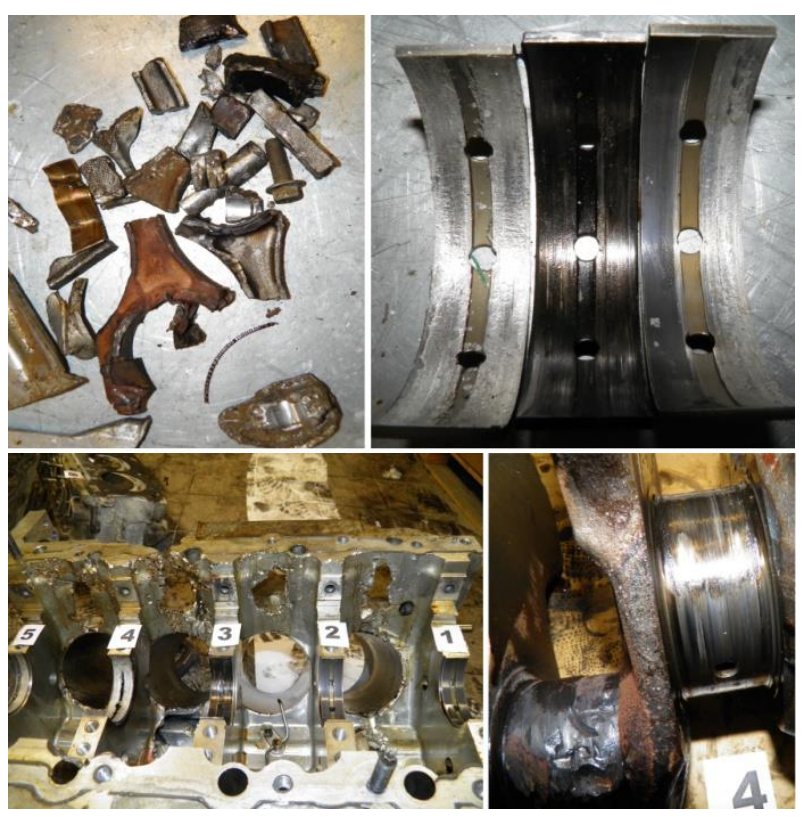

Рис. 7. Полное разрушение двигателя (вверху) с чрезвычайными повреждениями большинства коренных и шатунных вкладышей, коленчатого вала и множественными пробоями блока ичлиндров (внизу) - результат длительной работы двигателя на мощчностных режимах с неисправной системой смазки

На практике, помимо крайних ("чистых") случаев повреждения или только коренных, или только шатунных подшипников, исследователь сталкивается и с переходными состояниями, когда, например, повреждены все подшипники, но какие-то в большей степени, а какие-то в меньшей, что нередко связано со вторичными повреждениями деталей при продолжении работы двигателя после возникновения неисправности. Понятно, что прекращение эксплуатации двигателя сразу после появления признаков неисправности дает более четкую картину, в то время как любые вторичные повреждения могут в некоторых случаях "смазать" эту картину и затруднить определение причины неисправности. Тем не менее, сопоставление признаков повреждения подшипников конкретного двигателя с данными табл.1 позволяет достаточно быстро локализовать неисправность и путем ограниченного числа проверок также быстро выявить причину неисправности. При этом важно, что уточняется не только причина, но и в целом режим и длительность работы двигателя после возникновения неисправности, что может иметь решающее значение при некоторых видах исследований (например, для страховых компаний). 
Таблица 1. Характер повреждения подшипников коленвала в зависимости от вида неисправности системы смазки и режима работы двигателя

\begin{tabular}{|c|c|c|c|}
\hline $\begin{array}{l}\text { Главные признаки } \\
\text { неисправности (ка- } \\
\text { кая группа под- } \\
\text { шипников повре- } \\
\text { ждена) } \\
\end{array}$ & $\begin{array}{c}\text { Повреждены несколько } \\
\text { или все шатунные под- } \\
\text { шипники коленвала }\end{array}$ & $\begin{array}{c}\text { Повреждены несколько или все } \\
\text { коренные подшипники колен- } \\
\text { вала }\end{array}$ & $\begin{array}{c}\text { Повреждены и коренные, и } \\
\text { шатунные подшипники }\end{array}$ \\
\hline $\begin{array}{l}\text { Режимы работы } \\
\text { двигателя (оказы- } \\
\text { вают влияние на } \\
\text { характер повре- } \\
\text { ждения деталей) }\end{array}$ & $\begin{array}{l}\text { - пониженные обороты и } \\
\text { нагрузки, сравнительно } \\
\text { малое время работы по- } \\
\text { сле возникновения неис- } \\
\text { правности, } \\
\text { - повышенные нагрузки, } \\
\text { - увеличенная длительность } \\
\text { работы после возникнове- } \\
\text { ния неисправности } \\
\end{array}$ & $\begin{array}{l}\text { - пониженные обороты и } \\
\text { нагрузки, сравнительно малое } \\
\text { время работы после возникно- } \\
\text { вения неисправности, } \\
\text { - повышенные нагрузки }\end{array}$ & $\begin{array}{l}\text { - сравнительно длительная } \\
\text { работа двигателя на мощ- } \\
\text { ностных режимах после } \\
\text { возникновения неисправно- } \\
\text { сти }\end{array}$ \\
\hline $\begin{array}{l}\text { Подтверждающие } \\
\text { признаки (харак- } \\
\text { тер повреждения } \\
\text { деталей криво- } \\
\text { шипно-шатунного } \\
\text { механизма) }\end{array}$ & $\begin{array}{c}\text { - заклинивание коленвала в } \\
\text { шатунных подшипниках } \\
\text { на малых оборотах, } \\
\text { - проворачивание шатунных } \\
\text { вкладышей и поврежде- } \\
\text { ние кривошипн. головок } \\
\text { шатунов при повышении } \\
\text { нагрузки, } \\
\text { - перегрев и разрушение } \\
\text { кривошипной головки } \\
\text { шатуна при увеличении } \\
\text { длительности работы }\end{array}$ & $\begin{array}{l}\text { - заклинивание коленвала в ко- } \\
\text { ренных подшипниках на малых } \\
\text { оборотах, } \\
\text { - проворачивание коренных } \\
\text { вкладышей и повреждение ко- } \\
\text { ренных постелей в блоке ци- } \\
\text { линдров при увеличении } \\
\text { нагрузки }\end{array}$ & $\begin{array}{l}\text { - проворачивание шатунных } \\
\text { вкладышей и повреждение } \\
\text { кривошипных головок ша- } \\
\text { тунов с последующим их } \\
\text { разрушением, } \\
\text { - проворачивание коренных } \\
\text { вкладышей и повреждение } \\
\text { коренных постелей в блоке } \\
\text { цилиндров }\end{array}$ \\
\hline $\begin{array}{l}\text { Причины неис- } \\
\text { правности (нахо- } \\
\text { дятся по уточняю- } \\
\text { щим признакам - } \\
\text { состоянию кон- } \\
\text { кретных деталей) }\end{array}$ & $\begin{array}{l}\text { Снижение подачи масла к } \\
\text { коленвалу, в том числе: } \\
\text { - несвоевременный кон- } \\
\text { троль за уровнем масла, } \\
\text { - износ деталей масляного } \\
\text { насоса, } \\
\text { - износ коленвала и под- } \\
\text { шипников, } \\
\text { - загрязнение сетки масло- } \\
\text { заборника, } \\
\text { - чрезмерно низкая вяз- } \\
\text { кость масла }\end{array}$ & $\begin{array}{l}\text { Прекращение подачи масла к ко- } \\
\text { ленвалу, в том числе: } \\
\text { - заклинивание редукционного } \\
\text { клапана масляного насоса в от- } \\
\text { крытом положении, } \\
\text { - заклинивание редукционного } \\
\text { клапана маслонасоса в закры- } \\
\text { том положении, выдавливание } \\
\text { резинового кольца из-под мас- } \\
\text { ляного фильтра, } \\
\text { - неисправность механизма регу- } \\
\text { лирования объема нагнетатель- } \\
\text { ной полости маслонасоса, } \\
\text { - разрушение поддона картера, } \\
\text { - внутренние разрушения в дви- } \\
\text { гателе, влияющие на герметич- } \\
\text { ность и/или исправность мас- } \\
\text { лосистемы }\end{array}$ & $\begin{array}{l}\text { Возможные причины неис- } \\
\text { правности могут соответ- } \\
\text { ствовать как снижению, так } \\
\text { и полному прекращению } \\
\text { подачи масла: } \\
\text { - ключевое значение имеет } \\
\text { разница между состоянием } \\
\text { (степенью повреждения) } \\
\text { коренных и шатунных под- } \\
\text { шипников, } \\
\text { - чем дольше работает двига- } \\
\text { тель после появления неис- } \\
\text { правности, тем труднее } \\
\text { определить разницу между } \\
\text { состоянием (поврежде- } \\
\text { нием) коренных и шатун- } \\
\text { ных подшипников }\end{array}$ \\
\hline
\end{tabular}

\section{Заключение}

Наблюдаемое, согласно имеющимся экспериментальным данным, различие в повреждениях коренных и шатунных подшипников коленчатого вала при неисправностях в системе смазки вызвано различиями в организации подачи масла к подшипникам при влиянии центробежных сил и является ключевым фактором, указывающим на причину неисправности. Так, нарушение режима смазки и повреждение только коренных подшипников связано, главным образом, с быстрым и полным (или почти полным) прекращением подачи к ним масла, в то время как повреждение только шатунных подшипников является, как правило, следствием снижения подачи масла ниже некоего минимального уровня. Возможны и переходные состояния, когда повреждены и коренные, и шатунные подшипники, однако для правильного определения причины наиболее важна разница в степени их повреждения. При этом, если известные признаки повреждений подшипников разбить на главные (какая группа подшипников повреждена), подтверждающие (характер повреждений) и уточняющие (состояние деталей системы смазки), а затем проверять наличие указанных признаков при исследовании причин неисправностей в зависимости от разницы в состоянии коренных и шатунных подшипников, то причины неисправности двигателя, вызвавшие повреждение 
подшипников, могут быть определены с более высокой достоверностью.

\section{Список литературы:}

1. Greuter E. Engine Failure Analysis [Text] / Greuter Greuter E., Zima S. // SAE International, R-320, ISBN 978-0-76800885-2. Warrendale, USA. - 2012. - 582 р. 2. Копелиович Д. Как избежать отказов в работе подшипников скольжения [Текст] / Д.Копелиович // Автомобиль и сервис. - 2012. - №10. - С.62-64. 3. Копелиович Д. Вкладыши для двигателя - детали критические [Текст] / Д.Копелиович // Автомобиль и сервис. - 2012. - №8. - С.42-44. 4. Хрулев А.Э. Методика определения причины неисправности ДВС при тяжелых эксплуатационных повреждениях [Текст] / А.Э.Хрулев, Ю.В.Кочуренко // Двигатели внутреннего сгорания. - 2017. - №1. - С.52-59. 5. Хрулев А. Почему застучал вкладыш? [Текст] / А.Хрулев // Автомобиль и сервис. - 2000. - №12. - C.14-16. 6. Хрулев А. Подшипники двигателей [Текст] / А.Хрулев // Автомобиль и сервис. - 1998. №01. - С.41-44. 7. Чернавский С.А. Подшипники скольжения [Текст] / С.А.Чернавский //М.: Гос. научно-техн. изд. машиностроительной лит. - 1963. - 244 с. 8. Шаповалов В.В. Триботехника [Текст] / В.В.Шаповалов, В.А.Кохановский, А.Ч.Эркенов // Под ред. В.В.Шаповалова. - Ростов н/Д: Феникс, ISBN 978-5-222-25809-5, 2017. - 348 c. 9. Engine Bearings. Failure \& Analysis Guide [Text] // Clevite Issue form \#CBE-1-1208, Mahle Clevite Inc., Ann Arbor, Mi 48108, USA. - 2008. - 32 p. 10. Engine Bearings: Failure Analysis and Correction [Text] // MAHLE Aftermarket Inc. 23030 MAHLE Drive, Farmington Hills, MI 48335 USA. 2014. - 39p. 11. GLYCO. Engine Bearings. Catalogue
No.CATGY1201 [Text] // Federal-Mogul Global Aftermarket EMEA, Kontich, Belgium - 2013-2014. - 1321 p. 12. King Engine Bearings Catalogue [Text] // King Engine Bearings, Inc., 371 Little Falls Road, Suite 5, Cedar Grove, NJ 07009, USA. - 2016. - $554 p$.

\section{Bibliography (transliterated):}

1. Greuter E. (2012), Engine Failure Analysis / SAE International, $R$ 320, ISBN 978-0-7680-0885-2. Warrendale, USA. 582 p. 2. Kopeliovich D. (2012), How to avoid failures during sliding bearings working [Kak izbejat otkazov v rabote podshinikov skoljenia?] / Automobile \& Service, No.10, pp. 62-64. 3. Kopeliovich D. (2012), Engine bearings - critical components [Vkladyshi dlya dvigatelya - detali kriticheskie]/Automobile \& Service, No.8, pp. 42-44. 4. Khrulev A.E., Kochurenko Yu.V. (2017), Method for determining the cause of the ICE failure for severe damages in operation [Metodika opredelenia prichiny neispravnosti DVS pri tyajelyh ekspluatatcionnyh povrejdeniyah] / Internal combustion engines, No.1, pp. 52-59. 5. A Khrulev (2000), Why does the bearing knock? [Pochemu zastuchal vkladysh?] / Automobile \& Service, No.12, pp. 14-16. 6. Khrulev A (1998), Engine bearings [Podshipniki dvigatelei]/Automobile \& Service, No.1, pp. 41-44. 7. Chernavsky S.A. (1963), Sliding bearings [Podshipniki skoljenia] / Moscow: Gos. scientific and technical. ed. machine-building literature, 244 p. 8. Shapovalov V.V. (2017) Tribotechnics [Tribotekhnika] / Rostov n/D: Phoenix, ISBN 978-5-222 25809-5. - 348 p. 9. Engine Bearings. Failure \& Analysis Guide (2008) / Clevite Issue form \#CBE-1-1208, Mahle Clevite Inc., Ann Ar bor, Mi 48108, USA, 32 p. 10. Engine Bearings: Failure Analysis and Correction (2014) / MAHLE Aftermarket Inc. 23030 MAHLE Drive, Farmington Hills, MI 48335 USA, 39 p. 11. GLYCO. Engine Bearings. Catalogue No.CATGY1201 (2013-2014) / Federal-Mogul Global Aftermarket EMEA, Kontich, Belgium, 1321 p. 12. King Engine Bearings Catalogue (2016) / King Engine Bearings, Inc., 371 Little Falls Road, Suite 5, Cedar Grove, NJ 07009, USA, 554 p.

Поступила в редакиию 01.06.2018 2.

Хрулев Александр Эдуардович - канд. техн. наук, ст. науч. сотр., руководитель Международного Моторного Бюро, судебный эксперт, Киев, Украина, e-mail: alo.engine@gmail.com.

Кротов Максим Валерьевич - зам. руководителя Бюро моторной экспертизы Специализированного моторного центра "АБ-Инжиниринг", Москва, Россия, e-mail: ab@ab-engine.ru.

\section{ВПЛИВ ПОРУШЕНЬ У СИСТЕМІ ЗМАЩЕННЯ НА ХАРАКТЕР ПОШКОДЖЕННЯ ПІДШИПНИКІВ ДВЗ}

\section{О.Е. Хрулєв, М.В. Кротов}

Виконано аналіз стану підшипників ДВЗ при різних несправностях в системі змащення, які сприяють зменшенню або навіть повному припиненню подачі масла до підшипників колінчастого вала. Встановлено, що порушення подачі масла призводить до двох основних видів пошкоджень підшипників - коли пошкоджені тільки корінні підшипники, мова може йти про повне або майже повне припинення подачі масла, в той час як ушкодження тільки шатунних підшипників виникає при зниженні подачі масла. Виявлено, що різниця в характері ушкодження корінних і шатунних підшипників пов'язана не тільки 3 конструктивною відмінністю організації подачі масла, але і з дією відцентрових сил від обертання коленвала на стовп масла в змащувальному отворі, що подає масло до шатунних підшипників. Наведено та проаналізовано основні ознаки розглянутих видів ушкоджень, а шляхом поділу цих ознак на головні, що підтверджують і уточнюють, розроблені прості рекомендації по визначенню причин несправності ДВЗ, пов'язаних з ушкодженнями підшипників.

\section{THE INFLUENCE OF FAULTS IN THE LUBRICATION SYSTEM ON THE DAMAGE OF THE ENGINE BEARINGS \\ A.E.Khrulev, M.V.Krotov}

The analysis of the condition of the internal combustion engine bearings is carried out for various lubrication system faults, which cause a reduction or even complete stoppage of the oil supply to the bearings of the crankshaft. It is established that the oil supply failure leads to two main types of bearing damage: when only the main bearings are damaged, it can be a complete or almost complete stop of the oil supply, while damage to the connecting rod bearings only occurs when the oil supply decreases. It was found that the difference in the nature of damage to the main and connecting rod bearings is associated not only with the structural difference in the organization of the oil supply, but also with the effect of centrifugal forces from crankshaft rotation to the oil column in the lubricating hole supplying oil to the conrod bearing. The main signs of the types of damage are presented and analyzed, and by dividing these characteristics into the main ones, confirming and specifying, simple recommendations have been developed to determine the causes of engine failure associated with bearing damage. 


\title{
І.В. Парсаданов, В.В. Островерх, О.М. Клименко, Д.В. Павлов
}

\section{ОЦІНКА ВПЛИВУ ПОКРИТТЯ ПОВЕРХНІ ПОРШНІВ НА ПОКАЗНИКИ ДИЗЕЛЯ}

\begin{abstract}
Використання покриття поршнів дозволяє позитивно впливати на показники дизельного двигуна, що сприяє впровадженню різноманітних технологій покриття у виробниитво. Приватним підприсмством «Завод Двигун» (м. Мелітополь) впроваджено технологію нанесення покриття дисульфідом молібдену на бічну поверхню пориня і поверхню КЗ в поршні дизелів. Очінка впливу иієї технології на показники дизельного двигуна надана за результатами досліджень на кафедрі ДВЗ НТУ «ХПІ». Дослідження проведені на дизельному двигуні 4ЧН12/14 з безпосереднім впорскуванням палива, газотурбінним наддувом та проміжним охолодженням наддувного повітря із визначенням індикаторних діаграм, показників токсичності і димності відпрацьованих газів. При обробиі результатів досліджень враховувався вплив покриття поверхні камери згоряння на показники потужності, паливної економічності, нагароутворення. Позитивний ефект на процес згоряння в дизельному двигуні при використанні покриття пов'язане із зменшенням втрат на тертя $і$ зростанням теплоти, виділеної в початковий період згоряння. Підвищення швидкості згоряння дозволяє припустити поліпшення пристінкового сумішоутворення за рахунок підвищення температури стінок камери згоряння при ії теплоізолячіï. Деяке підвищення максимального тиску при малих потужностях не надасть негативного впливу на механічне навантаження дизеля.
\end{abstract}

Вступ

Певний резерв у поліпшені показників паливної економічності та екологічності дизелів існує при забезпеченні теплоізоляції КЗ [4-6] за рахунок прискорення підготовки палива до згоряння і зменшення втрат виділеної при згорянні теплоти в систему охолодження. Вищевказане обумовлює актуальність цього напряму модернізації ДВ3.

Приватним підприємством «Завод Двигун» (м. Мелітополь) на базі власних виробничих потужностей впроваджено технологію нанесення покриття дисульфідом молібдену на бічну поверхню поршня і поверхню КЗ в поршні дизелів.

Для оцінки ефективності вказаного заходу на кафедрі двигунів внутрішнього згоряння НТУ «ХПІ» проведено дослідження поршнів 3 покриттям поверхні камери згоряння, виготовлених за технологією ПП «Завод Двигун».

\section{Мета роботи}

Метою роботи $є$ визначення впливу покриття поршнів на показники автотракторного дизеля і надання оцінки щодо впровадження технології ПП «Завод Двигун» у виробництво.

За об'єкт дослідження обрано автотракторний дизель 4ЧН12/14, з рядним розташуванням циліндрів, рідинним охолодженням, з безпосереднім вприскуванням палива в камеру згоряння в поршні, газотурбінним наддувом та проміжним охолодженням наддувного повітря.

\section{Методика дослідження}

Дослідження проведено на стенді науково-дослідної лабораторії перспективних двигунів кафедри ДВЗ НТУ «ХПІ. При проведенні досліджень стенд було укомплектовано обладнанням для вимірювання концентрації у відпрацьованих газах оксидів азоту $\left(\mathrm{NO}_{x}\right)$, монооксиду вуглецю $(\mathrm{CO})$, а також димності відпрацьованих газів (N). Калібрування газо- аналізатору виконувалося безпосередньо перед випробуваннями та після них за допомогою еталонних повірочних газових сумішей.

Тепловий стан дизеля визначався за допомогою вимірювальної системи, що складається 3 хромель-алюмелевих термопар типу Т9Д та модуля вводу сигналів від термопар Advantech USB-4718, який обробляє, оцифровує та записує на жорсткий диск ЕОМ значення електрорухомої сили термопар.

Для індиціювання процесів у циліндрі ДВЗ і реєстрації тиску палива на вході у форсунку разом 3 реєстрацією переміщення голки розпилювача використано високотехнологічний комплекс на основі п'єзокварцового датчика AVL 8QP 505с та аналогоцифрового перетворювача L-Card 783-86. Запис сигналів на носій виконується за допомогою ліцензійного програмного забезпечення PowerGraph версії 3.2 Professional, яке забезпечує візуалізацію вимірюваного процесу.

Товщина нагару на поверхні камери згоряння вимірювалася товщиноміром WALCOM CM$8826 \mathrm{FN}$, робота якого основана на принципах магнітної індукції та вихрових токів.

Дослідження проведено з двома варіантами поршнів - вихідний варіант поршнів 23-0305А (рис. 1, a) та дослідний варіант поршнів з покриттям поверхні К3 (рис. 1, б). Товщина покриття складає 10 мкм. Обидва варіанта поршнів отримані від заводу-виробника та пройшли мікрометраж і обкатку на дизелі.

Випробування дизеля складалися 3 наступних етапів:

- зняття характеристики холостого ходу в діапазоні частот обертання колінчастого вала (КВ) $n=1000 \ldots 2000 \mathrm{xB}^{-1}$;

- зняття характеристики по куту випередження вприскування палива (КВВП, $\Theta$ ) на режимах $n=2000 \mathrm{xB}^{-1}, N_{e}=90$ кВт та $n=1500 \mathrm{xв}^{-1}$, $N_{e}=76$ кВт при значеннях $\Theta 14,18$ та 22 град. П.к.в. 
до ВМТ);

- зняття навантажувальних характеристик при частотах обертання КВ $n=2000$ і $1500 \mathrm{xB}^{-1}$.

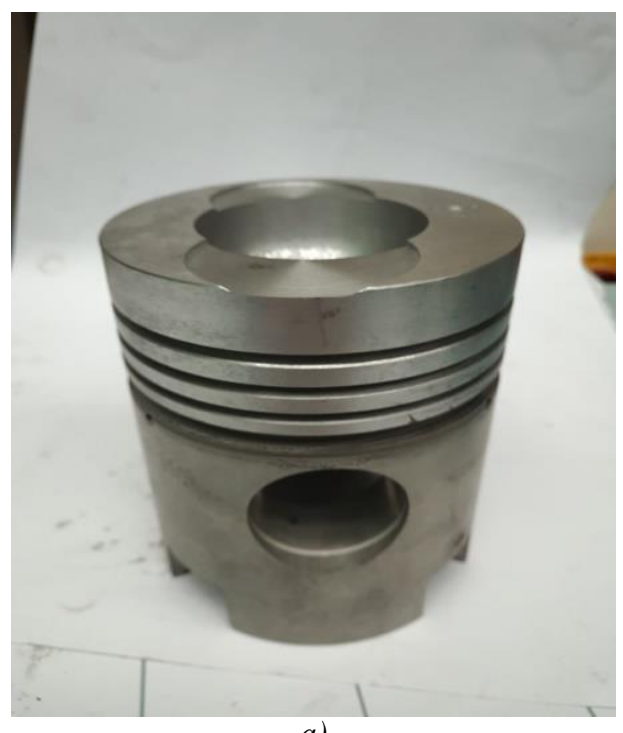

Рис. 1. Поршні:

a-23-0305А; 6 - дослідні поршні з покриттям поверхні КЗ виробництва ПП «ЗАВОД ДВИГУН»
КВВП при знятті характеристик холостого ходу і навантажувальних характеристик був незмінним і складав $\Theta=22$ град. п.к.в. до ВМТ.

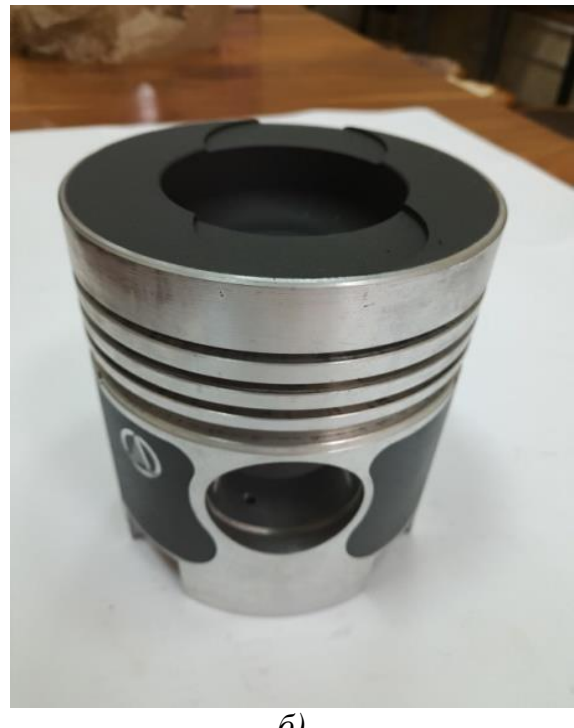

б)
На кожному режимі визначалися ефективні показники роботи двигуна: витрата палива, токсичність (концентрації оксидів азоту, монооксиду вуглецю) і димність відпрацьованих газів, режимні показники роботи дизеля; проводилося індиціювання двигуна.

Після завершення кожного циклу випробувань під час розбирання дизеля виконувалося вимірювання товщини шару нагару.

Дослідження проведені без заміни гільз циліндрів і поршневих кілець дизеля. При перебиранні перестановка поршнів і поршневих кілець в інші циліндри не допускалася.

Режими випробувань дизеля за навантажувальними характеристиками представлено у табл. 1 .

Реєстрація досліджуваних показників здійснювалася при усталених значеннях температур відпрацьованих газів, масла та охолоджуючої рідини. Заміри повторювалися $3 \ldots .5$ разів.

\section{Результати дослідження}

Результати досліджень дизеля щодо визначення впливу покриття поршня на годинну витрату палива для режимів холостого ходу в залежності від частоти обертання КВ наведено на рис. 2 .

Дані рис. 2 вказують на те, що на холостому ході розбіжність в годинній витраті палива при роботі дизеля з вихідним варіантом поршнів та варіантом поршнів 3 покриттям поверхні КЗ стає помітною 3 підвищенням частоти обертання КВ більш, ніж $n=1300 \mathrm{xB}^{-1}$. Так, на холостому ході при частоті обертання КВ $n=1400 \mathrm{xB}^{-1}$ дизеля 3 поршнями, що мають покриття поверхні КЗ, годинна витрата палива на $1,5 \%$ менше, а при частоті обертання КВ $n$ $=2000 \mathrm{xB}^{-1}-$ на $2,4 \%$ менше годинної витрати палива у порівнянні з поршнями 23-0305А (без покриття поверхні КЗ). Зменшення витрати палива на холостому ходу пов'язане із зниженням втрат на тертя в сполученні поршень - гільза.

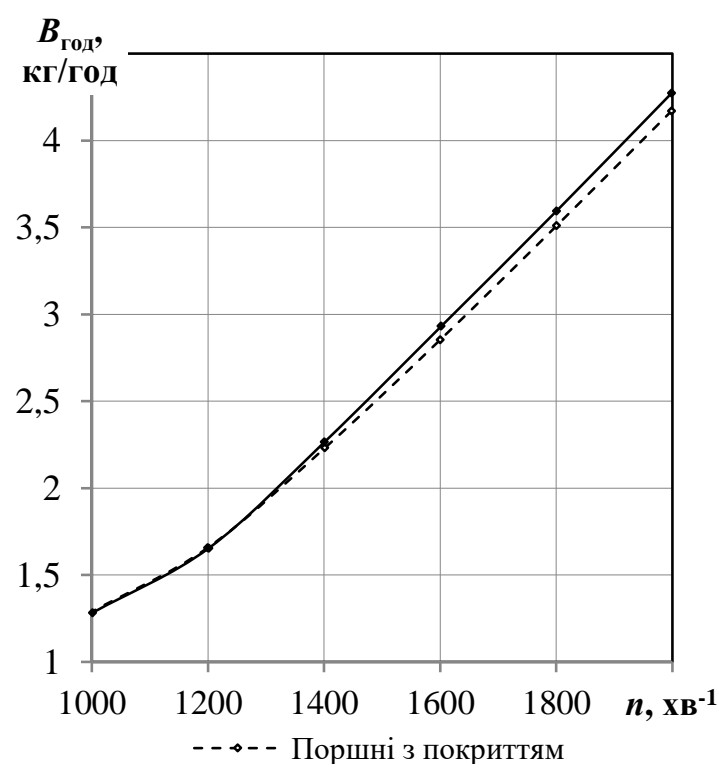

Рис. 2. Залежності годинної витрати палива від частоти обертання КВ при роботі дизеля на холостому ход $i$

Випробування дизеля за характеристикою по куту випередження вприскування палива показали, 
що характер впливу КВВП на витрату палива при роботі з поршнями 23-0305А та поршнями з покриттям КЗ не змінюється (рис. 3).

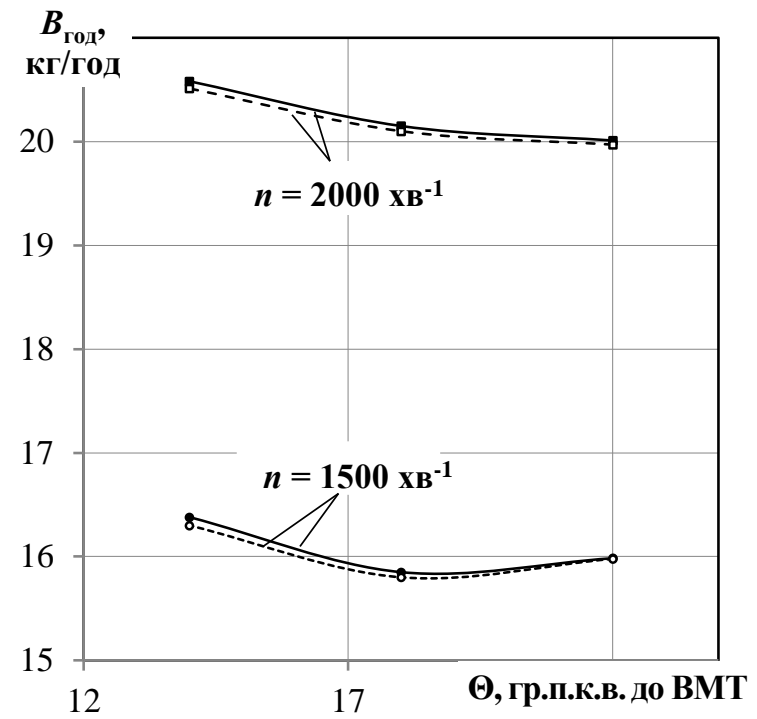

Рис. 3. Залежності годинної витрати палива від КВBП

Результати досліджень дизеля з вихідним варіантом поршнів та варіантом поршнів 3 покриттям за навантажувальними характеристиками при частотах обертання КВ $n=2000 \mathrm{xB}^{-1}$ та $1500 \mathrm{xB}^{-1}$ (рис. 4) свідчать, що із зменшенням потужності дизеля вплив покриття поршнів на годинну витрату палива зростає.

На рис. 5 наведено залежності питомої витрати палива $g_{e}$ та коефіцієнта надлишку повітря $\alpha_{p}$ від потужності при роботі дизеля за навантажувальними характеристиками. Видно, що економічна ефективність використання поршнів 3 покриттям виявляється при роботі дизеля на режимах із зниженим навантаженням. Коефіцієнт надлишку повітря, який міг би надавати вплив на характер перебігу паливної економічності, при цьому не змінюється у всьому діапазоні навантаження дизеля.

Температури відпрацьованих газів $t_{\mathrm{r}}$ при роботі дизеля з комплектом поршнів з покриттям поверхні КЗ нижче на режимах мінімальних навантажень (рис. 6). На режимах середніх і максимальних навантажень при частоті обертання КВ $n=2000 \mathrm{xB}^{-1}$ i $n=1500 \mathrm{xB}^{-1}$ різниця в температурах відпрацьованих газів незначна.

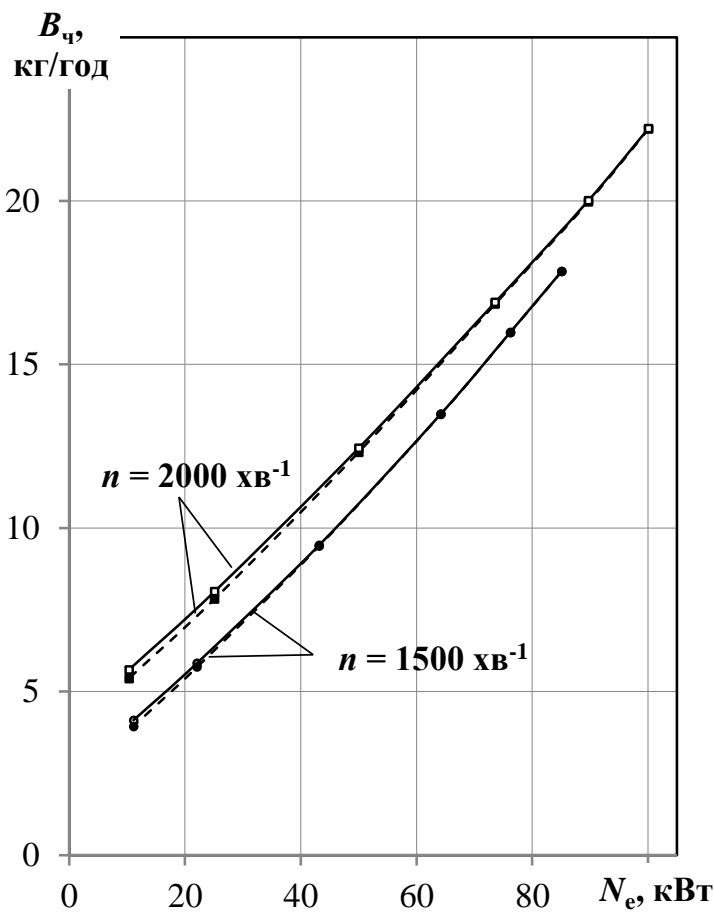

Рис. 4. Залежності годинної витрати палива від потужності дизеля при роботі за навантажувальними характеристикам

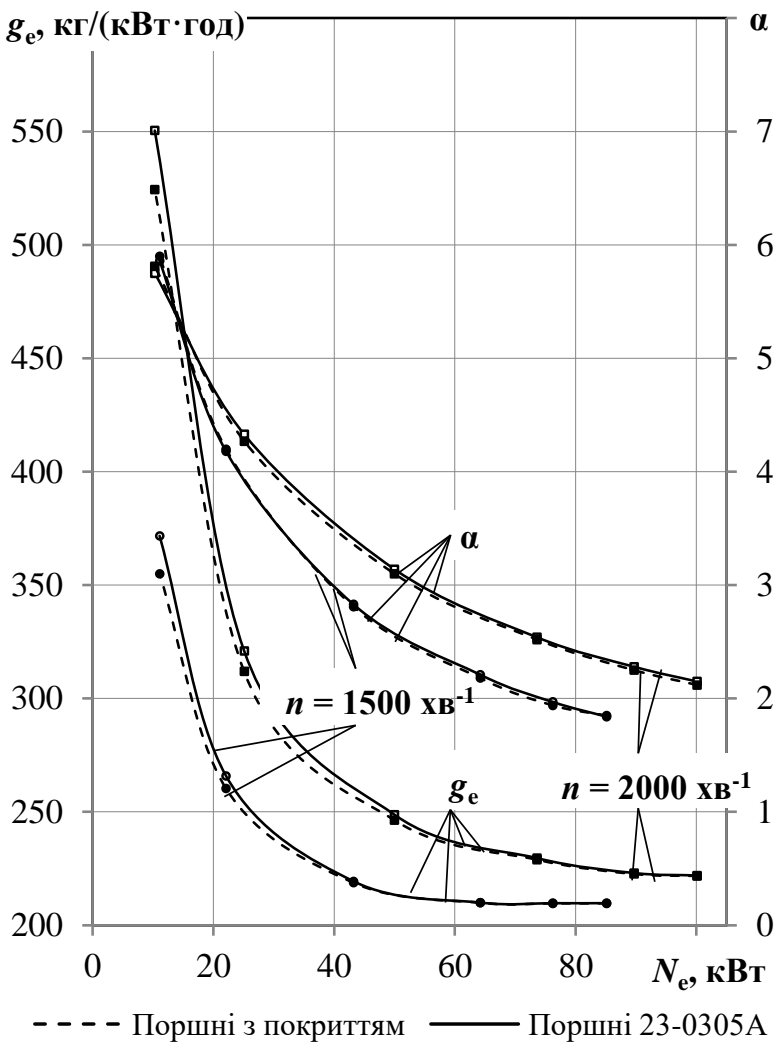

Рис. 5. Залежність питомої витрати палива та коефіиієнта надлишку повітря від потужності дизеля при роботі за навантажувальними характеристиками 


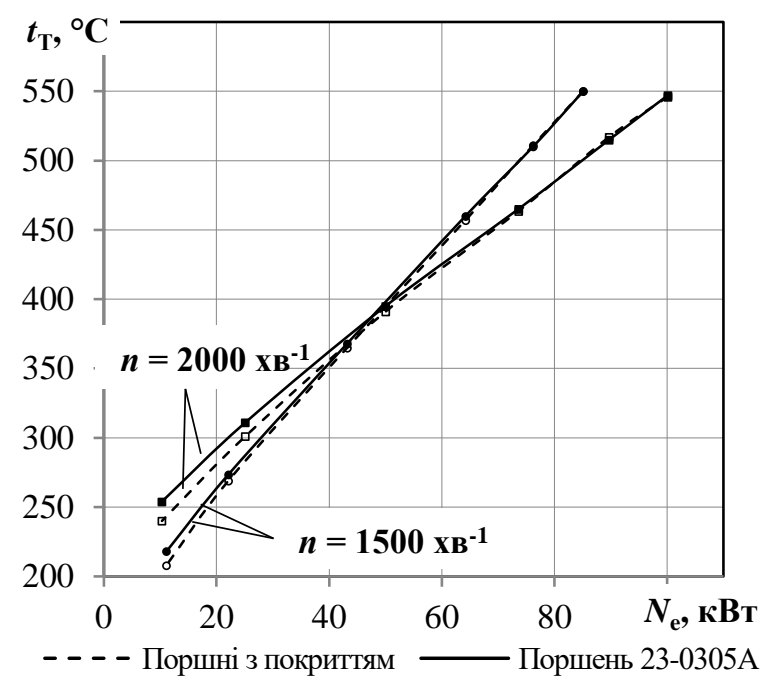

Рис. 6. Залежність температури відпращьованих газів від потужності дизеля при роботі за навантажувальними характеристиками

Така різниця в температурах відпрацьованих газів істотно не надає впливу на умови роботи турбіни турбокомпресора i не призводить до зменшення енергії відпрацьованих газів. Тиск повітря на виході з компресора та на вході в циліндри дизеля $p_{\mathrm{s}}$ залишається на одному рівні.

Відношення тиску повітря на вході в циліндри

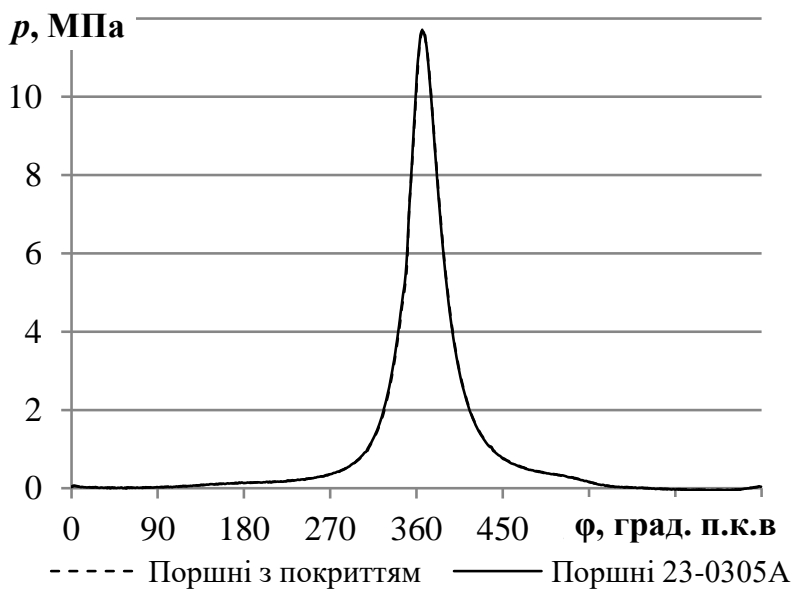

Рис. 7. Індикаторні діаграми дизеля при роботі на режимі $n=1500 \mathrm{xв}^{-1}, N_{e}=85 \mathrm{\kappa Bm}$

Збільшення максимального тиску згоряння сприяє зростанню теплоти, що виділяється в початковий період згоряння при спалаху палива. Позитивний вплив зростання тепловиділення може бути пов'язаний із прискоренням підготовки палива до згоряння і зменшенням втрат виділеної при згоряння теплоти в систему охолодження за рахунок до тиску відпрацьованих газів перед турбіною, яке характеризує роботу насосних втрат в дизелі, практично не відрізняється на порівняльних характеристиках роботи дизеля при частотах обертання КВ $n=$ $2000 \mathrm{xB}^{-1}$ та $1500 \mathrm{xB}^{-1}$.

Таким чином, за результатами досліджень можна констатувати, що при роботі за навантажувальною характеристикою $n=2000 \mathrm{xв}^{-1}$ питома витрата палива залишається незмінною при максимальній потужності і потужності 0,5 від максимальної, та зменшується при роботі дизеля із поршнями з покриттям при потужності $0,1 \ldots 0,5$ від максимальної на $2 \ldots 4,5 \%$. Така ж закономірність спостерігається і при роботі дизеля за навантажувальною характеристикою $n=1500 \mathrm{xB}^{-1}$.

Для аналізу індикаторних показників розглянуто індикаторні діаграми, одержані при роботі дизеля при частоті обертання колінчастого валу $n=$ $=1500 \mathrm{xв}^{-1}$ на режимах $N_{\mathrm{e}}=85$ кВт і $N_{\mathrm{e}}=22$ кВт 3 поршнями без покриття і 3 покриттям поверхні КЗ, (рис. 7 та 8).

Видно, що при потужності дизеля 85 кВт індикаторні діаграми та максимальний тиск згоряння повністю збігаються. В той же час при потужності 22 кВт максимальний тиск згоряння вище на 0,5 МПа при роботі дизеля з поршнями з покриттям поверхні КЗ.

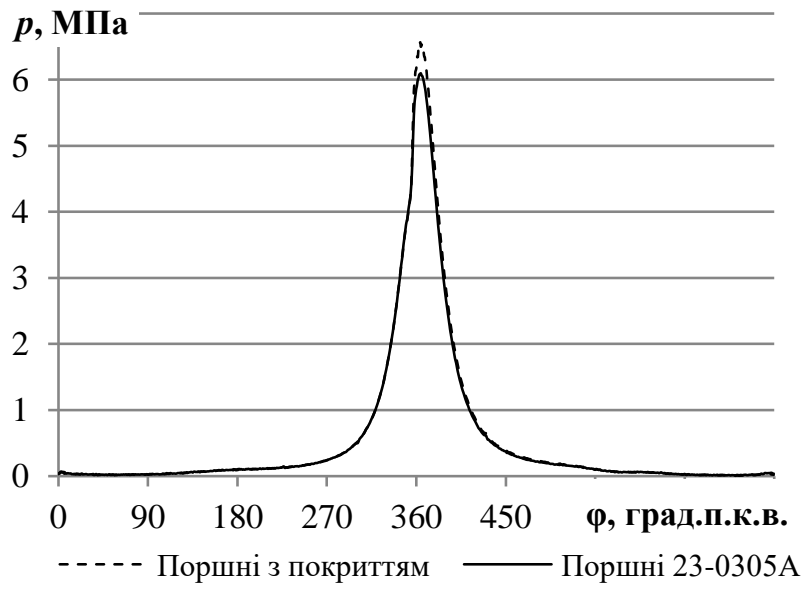

Рис. 8. Індикаторні діаграми дизеля при роботі на режимі $n=1500 \mathrm{xв}^{-1}, N_{e}=22 \mathrm{\kappa Bm}$

теплоізоляції при нанесенні покриття.

Максимальний тиск згоряння $p_{\mathrm{z}}$, характеризує механічне навантаження на дизель. Залежності максимального тиску згоряння що визначені по індикаторним діаграмам, наведено на рис. 9 і 10. 


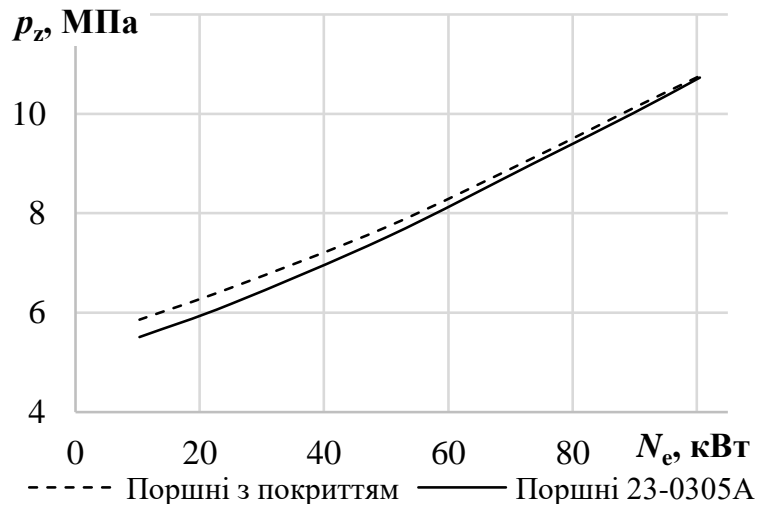

Рис. 9. Максимальний тиск згоряння в циліндрі дизеля при роботі за навантажувальною характеристи кою $n=2000 x^{-1}$

3 наведених даних випливає, що максимальний тиск згоряння при роботі дизеля з поршнями 3 покриттям КЗ незначно підвищився в порівнянні з роботою дизеля 3 поршнями без покриття головним чином при потужності $0,1 \ldots 0,5$ від максимальної для обох досліджених частот обертання КВ. Деяке підвищення максимального тиску при малих потужностях не оказує негативного впливу на механічне навантаження дизеля.

Результати дослідження димності та токсичності відпрацьованих газів при роботі дизеля з поршнями 23-0305А та поршнями з покриттям поверхні КЗ виробництва ПП «Завод Двигун» наведені на рис. $11 \ldots 13$.

3 наведених даних можна відмітити деяке покращення показника димності відпрацьованих газів на всіх досліджуваних режимах при роботі з поршнями з покриттям поверхні КЗ (рис. 11).

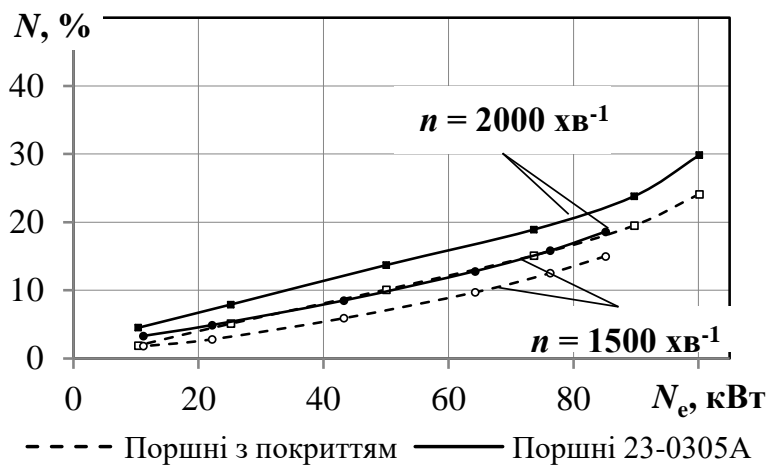

Рис. 11. Залежність димності відпраџьованих газів від потужності дизеля

Найбільший позитивний ефект при випробуванні поршнів 3 покриттям КЗ одержаний від зменшення викиду 3 відпрацьованими газами монооксиду вуглецю. Наведені на рис. 12 дані свідчать, що при дослідженнях дизеля 3 поршнями 3 покриттям К3 зменшення концентрації СО у ВГ складає

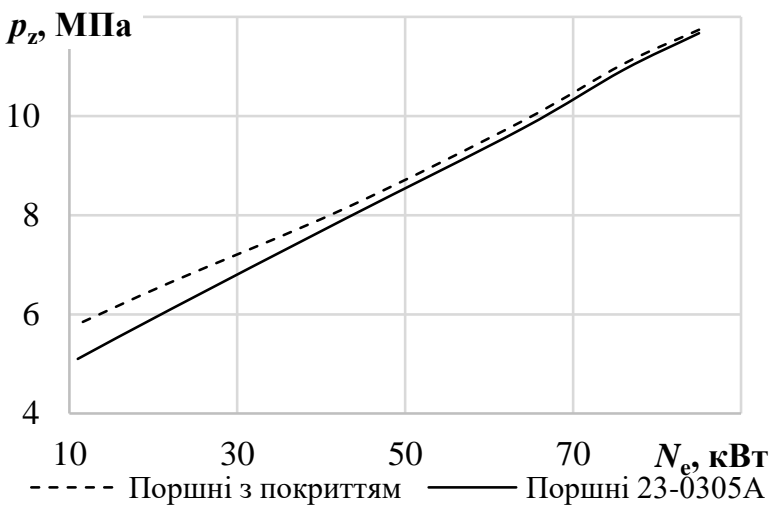

Рис. 10. Максимальний тиск згоряння в циліндрі дизеля при роботі за навантажувальною характеристикою $n=1500 \times \mathrm{B}^{-1}$

$180 \ldots 250$ млн $^{-1}$ при $n=1500 \mathrm{xв}^{-1}$ та $140 \ldots 170$ млн $^{-1}$ при $n=2000 \mathrm{xB}^{-1}$ у всьому діапазоні навантажень дизеля.

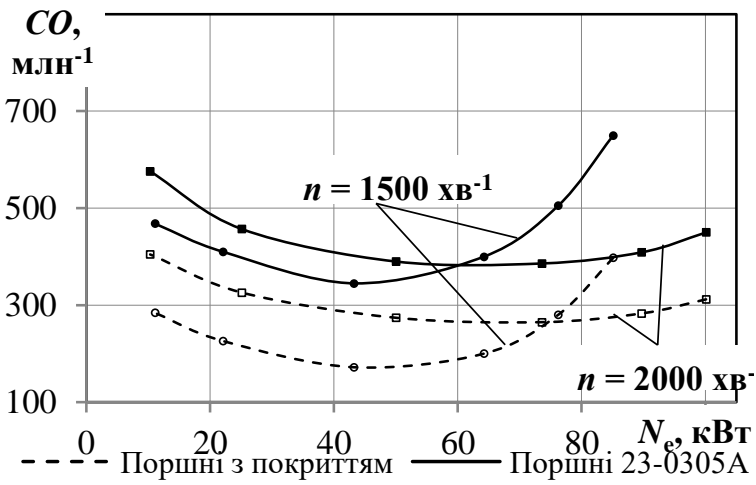

Рис. 12. Залежність конщентрації монооксиду вуглеиюю у відпрацьованих газах від потужності дизеля

Водночас слід відмітити деяке зростання концентрації оксидів азоту $\mathrm{NO}_{x}$ у відпрацьованих газах при роботі дизеля з поршнями 3 покриттям КЗ відносно поршнів без покриття. 3 рис. 13 можна відмітити зростання $\mathrm{NO}_{\mathrm{x}}$ на $50 \ldots 150$ млн $^{-1}$ при потужності дизеля від 0,5 до максимальної для обох частот обертання КВ.

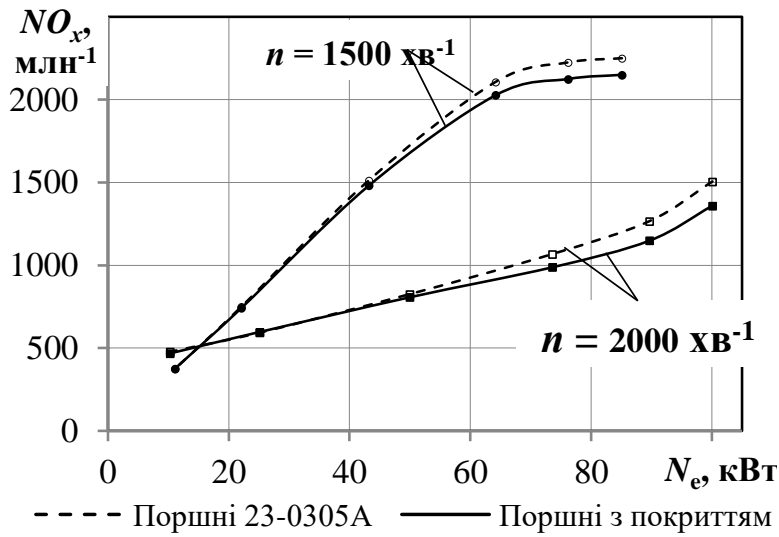

Рис. 13. Залежність концентрації оксидів азоту у відпрацьованих газів від потужності дизеля 
Таким чином, результати дослідження впливу покриття поршнів на показники димності та токсичності відпрацьованих газів показали, що збільшення температури робочого тіла в циліндрі дизеля, яке $\epsilon$ результатом впливу теплоізоляційних властивостей і особливостей технології покриття КЗ, має позитивний вплив на димність і викиди монооксиду вуглецю, проте приводить до деякого збільшення викиду оксидів азоту.

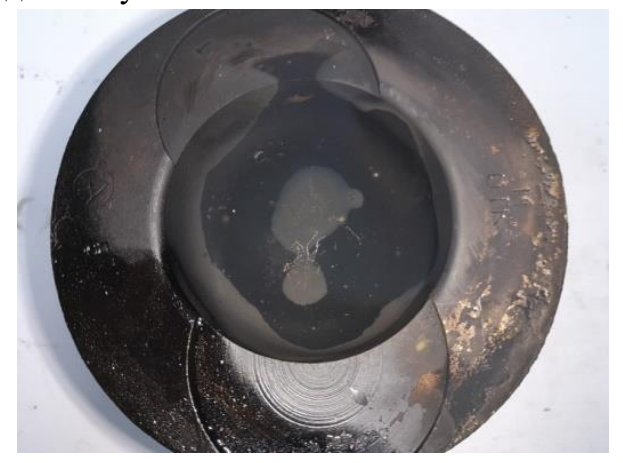

Після завершення кожного циклу випробувань під час розбирання дизеля виконувалося вимірювання товщини шару нагару товщиноміром WALCOM CM-8826FN.

Дослідження виявило зменшення ступеня нагароутворення при використанні дослідних поршнів виробництва ПП «Завод Двигун» (рис. 14, 15).

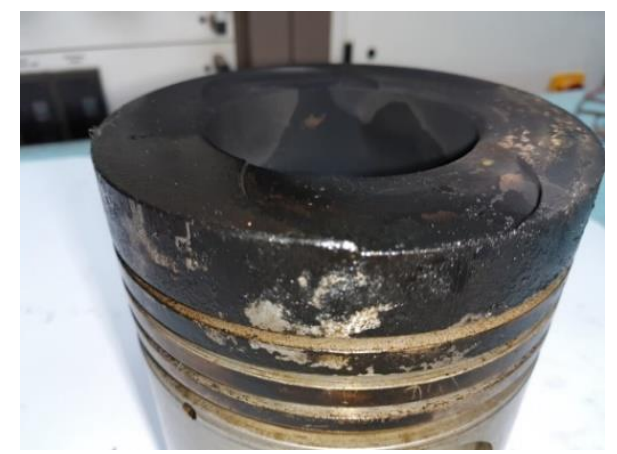

Рис. 14. Поршні 23-0305А після ииклу випробувань
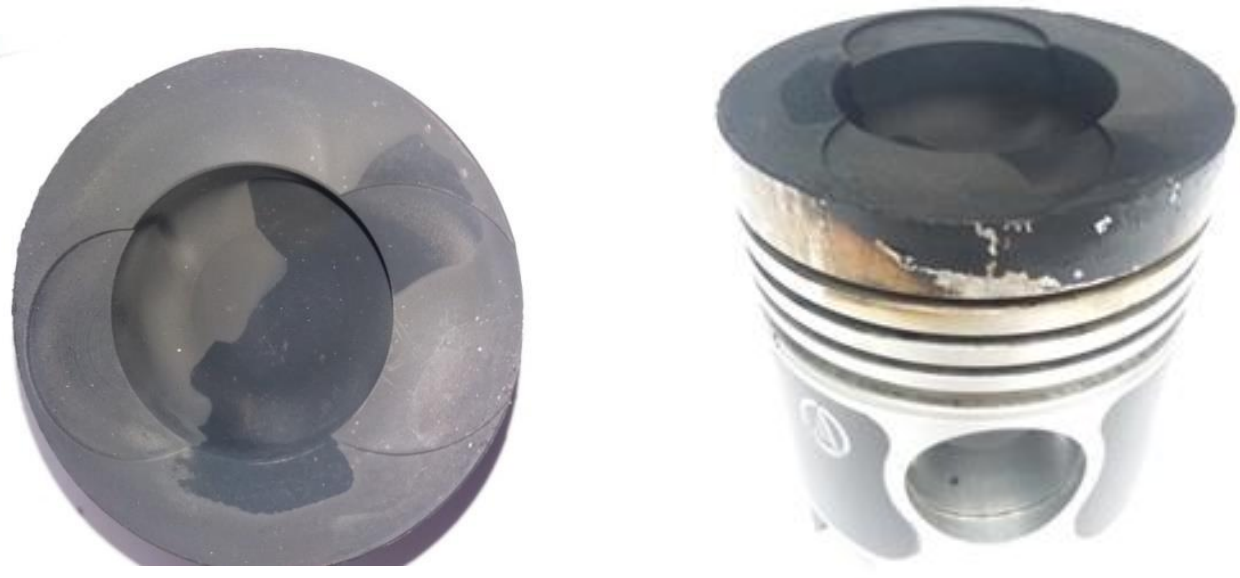

Рис. 15. Дослідні порині з покриттям поверхні КЗ після цุиклу випробувань

В результаті випробувальних циклів навантаження протягом 16 годин на поверхнях камери згоряння в поршні та головки циліндрів і бічної поверхні поршня вище першого поршневого кільця поршня 23-0305А утворився шар нагару (переважно в лакоподібному стані) товщиною $170 \ldots 250$ мкм (див. рис. 14).

При роботі дизеля з поршнями з покриттям поверхні камери згоряння (рис. 15), товщина утвореного шару нагару склала $5 \ldots 15$ мкм. Причому нагар знаходився виключно в порохоподібному стані. На поверхнях поршня, де було відсутнє покриття (периферія верхньої поверхні головки поршня, бічна поверхня поршня вище першого поршневого кільця), виявлено нагар в порохо- та лакоподібному стані товщиною $70 \ldots 120$ мкм.

Тобто, використання дослідних поршнів 3 покриттям поверхні камери згоряння зменшує ступінь нагароутворення. Вищевказане виявляє можливість покращити надійність циліндро-поршневої групи та двигуна в цілому при використанні дослідних поршнів 3 покриттям поверхні камери згоряння.

\section{Висновки}

В результаті оцінки впливу покриття поршнів виробництва ПП «Завод Двигун» на показники дизеля встановлено наступне.

3 точки зору паливної економічності покриття поверхні поршнів найбільш ефективне для режимів малих навантажень і холостого ходу. На холостому ході розбіжність в годинній витраті палива при роботі дизеля з вихідним варіантом поршнів та дослідним варіантом поршнів 3 покриттям поверхні камери згоряння стає помітною 3 підвищенням частоти обертання колінчастого вала більш, ніж $n=$ $1300 \mathrm{xB}^{-1}$. 
Поліпшення паливної економічності дизеля пов'язане із зниженням втрат на тертя і зростанням теплоти, виділеної в початковий період згоряння. Підвищення швидкості згоряння дозволяє припустити поліпшення пристінкового сумішоутворення за рахунок підвищення температури стінок камери згоряння за рахунок ії теплоізоляції. Деяке підвищення максимального тиску при малих потужностях не надасть негативного впливу на механічне навантаження дизеля.

При роботі з поршнями 3 покриттям поверхні К3 відзначається зниження димності відпрацьованих газів і концентрації монооксиду вуглецю, водночас має місце деяке зростання концентрації оксидів азоту у відпрацьованих газах.

Використання покриття поверхні камери згоряння поршнів дозволяє зменшити ступінь нагароутворення, що виявляє можливість покращити надійність циліндропоршневої групи дизеля.

\section{Список літератури:}

1. Парсаданов И.В. Повышение качества и конкурентоспособности дизелей на основе комплексного топливно- экологического критерия: Монография / И.В. Парсаданов. - Харьков: НТУ «ХПИ», 2003. - 244 c. 2. Smavik Magnus B. Thermal barrier influence on performance and heat transfer of a medium speed two-stroke diesel engine / B. Smavik Magnus // SAE Technical Paper Series. - 1988. - №880435. - P. 153-162. 3. A structural ceramic diesel engine - the critical elements / W. R. Wade, P. H. Hanstad, V. D. Rao et al. // SAE Technical Paper Series. - 1987. - №870651. - P. 251-264. 4. Morel T. Heat transfer experiments in an insulated diesel / Morel T., Wahiduz Z. S., Fort E. F. // SAE Technical Paper Series. - 1988. - №880186. - P. 61-81.

\section{Bibliography (transliterated):}

1. Parsadanov I., (2003), Improving the quality and competitiveness of diesel engines on the basis of an integrated fuel and ecological criteria: Monograph [Povyshenie kachestva i konku-rentosposobnosti dizelej na osnove kompleksnogo toplivno-ehkologicheskogo kriteriya: Monografiya], Kharkov, NTU "HPI", 244 p. 2. Smavik Magnus B., (1988), Thermal barrier influence on performance and heat transfer of a medium speed two-stroke diesel engine, SAE Technical Paper Series, №880435, pp. 153-162. 3. W. R. Wade, P. H. Hanstad, V. D. Rao et al, (1987), A structural ceramic diesel engine - the critical elements, SAE Technical Paper Series, №870651, pp. 251-264. 4. Morel T., Wahiduz Z. S., Fort E. F., (1988), Heat transfer experiments in an insulated diesel, SAE Technical Paper Series, №880186, pp. 61-81.

Надійшла до редакиії 11.07.2018p.

Парсаданов Ігор Володимирович - докт. техн. наук, проф., гол. наук. співр. кафедри двигунів внутрішнього згоряння Національного технічного університету «Харківський політехнічний інститут», Харків, Україна, e-mail; parsadanov@kpi.kharkov.ua, http://orcid.org/0000-0003-0587-4033.

Островерх Вадим Вікторович - директор ПП «Завод Двигун», Мелітополь, Україна.

Клименко Олександр Миколайович - канд. техн. наук, науковий співробітник кафедри двигунів внутрішнього згоряння Національного технічного університету «Харківський політехнічний інститут», Харків, Україна, е-таil: klim23051987@gmail.com.

Павлов Дмитро Вікторович - інженер-конструктор ПП «Завод Двигун», Мелітополь, Україна.

Строков Олександр Петрович - докт. техн. наук, проф., професор кафедри автомобільного та транспортних технологій Класичного приватного університету, Запоріжжя.

\section{ЭКСПЕРИМЕНТАЛЬНОЕ ИССЛЕДОВАНИЕ ВЛИЯНИЯ ПРИМЕНЕНИЯ ПОКРЫТИЯ КАМЕРЫ СГОРАНИЯ В ПОРШНЕ НА ТОПЛИВО-ЭКОЛОГИЧЕСКИЕ И ЭФФЕКТИВНЫЕ ПОКАЗАТЕЛИ ДИЗЕЛЯ}

\section{И.В. Парсаданов, В.В. Островерх, А.М. Клименко, Д.В. Павлов, А.П. Строков}

Работа посвящена анализу комплексного влияния покрытия камеры сгорания поршней производства ЧП «Завод Двигатель» на показатели автотракторного дизеля. При выполнении работы проведены стендовые исследования, определены эффективные и индикаторные показатели, концентрации токсичных веществ в отработавших газах, дымность отработавших газов и степень нагарообразования при работе автотракторного дизеля с опытными поршнями (с покрытием поверхности камеры сгорания) по сравнению с поршнями 23-0305А (без покрытия). Результаты проведенных исследований являются основой для оценки экономической и экологической эффективности использования технологии покрытия камеры сгорания поршней производства ЧП «Завод Двигатель» в эксплуатации.

\section{EXPERIMENTAL STUDY OF THE INFLUENCE OF THE APPLICATION OF COATING OF THE COMBUSTION CHAMBER IN THE PISTON ON FUEL AND ENVIRONMENTAL AND EFFECTIVE DIESEL INDICATORS}

\section{I.V. Parsadanov, V.V. Ostroverkh, OM Klimenko, D.V. Pavlov, A.P. Strokov}

The work is devoted to the analysis of the complex effect of the coating of the combustion chamber of pistons produced by PE «Zavod Dvigatel» on the parameters of an automotive tractor diesel engine. During the performance of the work bench tests were conducted, the effective and indicator indicators, the concentrations of toxic substances in the exhaust gases, the smoke of the exhaust gases and the degree of carbon formation during the operation of an autotractor diesel engine with pilot pistons (with the surface of the combustion chamber) compared to the pistons 23-0305A). The results of the studies are the basis for assessing the economic and environmental efficiency of using the technology of coating the combustion chamber of pistons produced by PE «Zavod Dvigatel»in operation. 